Contents list available at IJRED website

Int. Journal of Renewable Energy Development (IJRED)

Journal homepage: www.ijred.com

\title{
Empowering Distributed Solar PV Energy for Malaysian Rural Housing: Towards Energy Security and Equitability of Rural Communities
}

\author{
N.A. Ahmad ${ }^{* a b}$, and H. Byrdb \\ ${ }^{a}$ Department of Building Surveying, Faculty of Architecture, Planning and Surveying, \\ UniversitiTeknologi MARA (UiTM), 32610, Perak, MALAYSIA
}

${ }^{b}$ School of Architecture and Planning, NICAI, The University of Auckland, 1010, NEW ZEALAND

\section{Article history:}

Received Dec 5, 2012

Received in revised form Jan 19, 2013 Accepted January 25, 2013 Available online

\begin{abstract}
This paper illustrates on how Malaysia's development landscapes has been powered by cheap oil and gas making it dependent and addicted on using large amounts of fossil fuels. As a country that is primarily depended on fossil fuels for generating power supply, Malaysia needs to cogitate of long-term energy security due to fossil fuel depletion and peak oil issues. Loss of these resources could leadto thereduction of power generation capacitywhich will threaten the stability of the electricity supply in Malaysia. This could potentially influence in an increase in electricity costs which lead to a phase of power scarcity and load shedding for the country. With the risk of interrupted power supplies, rural households, especially those of low-income groups are particularly vulnerable to the post-effects of a power outage and an inequitable distribution to the people. Distributed generation of electricity by solar PVs diminishes the vulnerability of these households and can also offer an income to them by feeding the power supply to the national grid through Feed-in Tariff scheme. At the moment, the deployment of solar PV installations is still in the introductory stage in Malaysia, where roof-mounted PV panels are only available to commercial and urban residential buildings. This is due to the lack of a suitable renewable energy policy for rural households and the high cost of the solar PV technology. This paper will put forward an analysis for incorporating solar photovoltaic on roofs of rural houses by identifying the energy consumption of these households and the extent to which PVs can alleviate electricity insecurity. The results present significant potential for distributed PV power generation in rural areas in Malaysia which shown a considerable amount of electricity needed to be harvested from roofmounted solar PV for rural people in Malaysia.
\end{abstract}

Keywords: feed-in tariff, cost-benefit analysis, pay-back period, photovoltaic, rural housing

\section{Introduction}

For the past 40 years, Malaysia has been experiencing a growing electricity demand from 336 MW in 1965 (Naidu 2010) to 15, 476 MW in 2011 (Noh 2012). Population growth, subsidized fuel prices, rising domestic incomes and the inexpensive cost of electrical appliances have all encouraged energy demand in Malaysian domestic sectors and caused people to consume more electricity (Malaysia 2012).

Data in 2011 has shown that fossil fuels have a significant role in electricity generation in Malaysia, where it is mainly generated from non-renewable resources and dominates $94 \%$ of total energy mix (Naidu 2010). The record shown that electricity in Peninsular Malaysia is powered by resources of natural gas $(45 \%)$, followed by imported coal (44\%), hydro $(5.7 \%)$, oil and petroleum $(2.5 \%)$, distillate resources $(2.5 \%)$ and small portion of imported resources $(0.3 \%)$ (Noh 2012) (see Fig. 1).

With the aid of highly subsidized rate for electricity at 21.8 RM sen/kWh (TNB 2010), Malaysia's electricity consumption continues to escalate every year. A record from The Energy Commission of Malaysia has shown -

*Corresponding author:

Email: nahm066@aucklanduni.ac.nz 


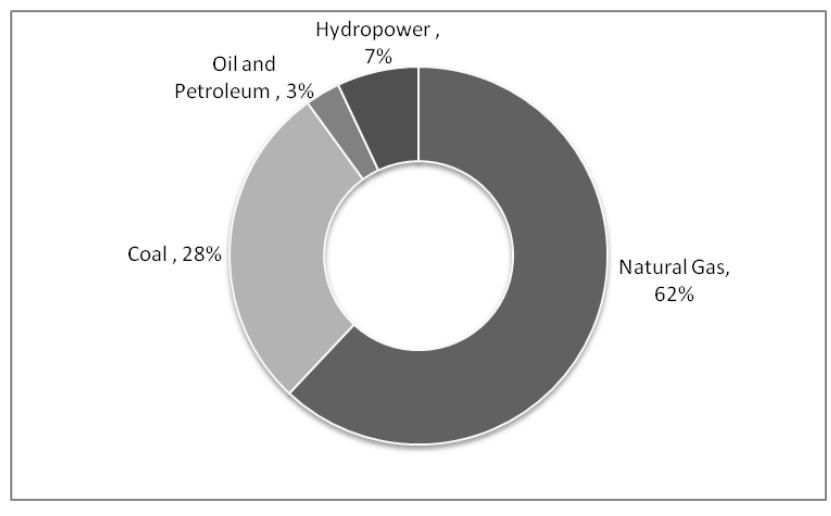

Fig. 1 Electricity Sector Energy Mix in Malaysia 2005 (adapted from Noh 2012)

that the electricity demand for the housing sector alone has experienced about 4.9 percent growth per year for over the past 10 years (Suruhjaya 2007) which proven thatthe population has become largely dependent on cheap electricity. Factors such as cheap electrical appliances market (Saidur 2007) and improved standard of living (APEC 2006) have helped to encourage this growth rate. The Energy Commission of Malaysia stated that, as of June 2007, Malaysia had among the lowest electricity tariffs for households' worldwide (7.42 US cents/1kWh) (Suruhjaya 2007).

However, fulfilling the growing demands of electricity for the nation has become more and more difficult due to the occurrence of fossil fuels depletion issues. With the main resources for generating electricity are based on non-renewables energy and under threat due to the peak oil issue, there is a risk of an inadequate supply of electricity. This will potentially raises issues of power rationing or load shedding which will affect many people, especially for low income groups in rural communities. Many do not realize that the inadequacy of electricity will affect not only the industrial and commercial sectors in Malaysia, but also the rural population who are unable to generate their own electricity. At the moment, there are no serious issues on rural electrification in Malaysia as reflected in the Tenth Malaysian Plan (Malaysia 2010), but in the near future, when the energy resources diminish, the problem associated with inadequacy power supplies will regularly affects the people. These people are more vulnerable when facing frequent power blackouts since they are fully reliant on electricity supplied by the Government.Rolling blackout or load-shedding is an event that occurs regularly in many parts of the world (Arun 1991; California energy Commision 2012), especially in the rural areas due to insufficient generation capacity to supply sufficient power to the area where it is needed (Mohamed \& Lee 2006). This is a last resort strategy that usually happens during peak hours when demand for electricity starts to surpass the local utility's available supply and power in selected areas has to be shut down. As many developed and developing countries in the world are facing this situation (Arun 1991; Harrabin 2009; Luke 2010), Malaysia, sooner or later, might be facing the same situation and usually rural populations will have to face the consequences. It is often to see in many countries, where rural areas will have to face government decision on shutting the power for certain times (Arun 1991) in order to secure the electricity supplies for commercial and industrial areas in the city (Campren et al. 2000).

Due to this, Malaysia requires a more resilient electricity supply to mitigate any future risk of power rationing and this can be achieved by empowering distributed solar PV energy for rural residential area in Malaysia. In this paper, we examine the electricity load profile of selectedhouses in rural areas in order to extend the feasibility study of potential distributed solar $\mathrm{PV}$ energy in this area by using roof-mounted solar PV.

\section{Energy Security and Subsidy: The Case of Malaysia}

An estimated $30 \%$ of 28 million people in Malaysia are part of the low income group, mainly living in rural areas (Department of Statistic Malaysia 2011). Unlike many Asian countries, electricity coverage in rural Malaysia operates 24 hours a day throughout the country, with the coverage expanding from $79 \%$ in the 1970 to $94 \%$ in the year 2009 (TNB 2009). One of the most crucial issues linked to energy security in Malaysia is the assurance of an uninterrupted electricity supply (Byrd 2010b). With an insecure supply of energy there is a risk of an inadequate supply of electricity which raises issues of an inequitable electrical power distribution to the population, especially for rural people.

According to the US Energy Information Administration, Malaysia's oil reserves have declined in recent years, from 771,000 barrels/day in 2000 to 703,920 barrels/day in 2007 (EIA 2010). CIA World Factbook has reported that Malaysia has produced an average of 603,400 barrels per day (Ali et al. 2012) in the year 2011, which clearly shown that there wasdepletion in oil reserves. As highlighted by the CEO of TNB, there is a need to import natural gas since future demand cannot be met from indigenous sources (Noh 2012). Apart from that, the coal reserves which is fully imported, is exposed to the risk of inadequate supply due to competition from other countries, especially from China and India (IEA 2012), and political issue (Muri 2003). Since petrol and diesel are connected to the global market prices, peak oil is now a significant issue for Malaysia's energy security. The gap in fuel supply at power generation plants has to be evaded in order to avoid any related issues of power blackouts.

One of the most concern issues related with energy security is the energy subsidy provided from the Government to the people. Energy subsidy is considered 
as an effective political tool to enhance the economy of Malaysian, especially the low-income groups and rural people who have constraints of funds and financial matters (Economic Planning Unit 2005). In addition, subsidy is a very significant factor in determining electricity price in Malaysia (Hamid \& Rashid 2012) . Due to natural gas depletion issues (EIA 2008) and increases in international coal prices (IEA 2012), interruption of gas supply experienced by the national power corporation company (known as Tenaga Nasional Berhad) have resulted in rising operating costs.

Malaysia is to be expected to hold market-driven gas price by 2015 as it progressively removes gas price subsidy over the next 4 years (Hamid \& Rashid 2012). At the moment, the current gas price paid by the power sectors is at a huge discount of 71-76\% (RM13.70 and RM16.07 per mmBtu)(Hann 2012) if to be compared with the LNG Asia-Pacific LNG price of RM56/mmBtu (International Gas Union 2011). Since the gas price is heavily subsidized, it will cause hikes in electricity tariffs in the new future due to the removal of subsidy (Hamid \& Rashid 2012). As a knock-on effect, with the higher demand of electricity from the people and reduced subsidy, it will increase the price of electricity.

Under many circumstances, rural communities will have to face the consequences of this removal subsidy.Due to the energy gap, the possibility of interrupted electricity supplies which will lead to frequent power blackouts will also occurs. With the combination of these factors, social disruption event will emerge. Many researchers have reported on the issues of safety, the emergence of crime, disruption of traffic, health disorder and loss of communication in the event of blackouts in many developing countries (Arun 1991; Byrd 2010a; Byrd 2010b; Luke 2010). Load shedding (turning electricity off in one area in order to keep an adequate supply in another) requires complex decisions in order to prioritize the electricity supply to communities (Byrd 2010b). To protect low income households, special rebates were given for domestic electricity units consumed during the recent electricity tariff hike (Malaysia 2010; Hamid \& Rashid 2012), but this is still not a sustainable move.

In this context, distributed renewable energy resources, especially solar photovoltaic (PV), are likely to play an important role in overcoming the problems of load-shedding and mitigating the energy security issues. With a significant empowerment of suitable policy, Malaysia has the potential to exploit solar energy, in particular PVs to generate electricity for the people, especially for rural communities. At the moment, a strategic measure in government policy in support of the renewable energy market, particularly solar energy, is still lacking. The current diffusion mechanisms are not sufficient to develop solar energy potential throughout the country (Ab Kadir et al. 2010), especially in rural areas.
Experiences from many countries clearly show that a move towards dissemination of roof-mounted solar $\mathrm{PV}$ energy is essential in order to mitigate future risk of energy insecurity for the people(Watson et al. 2008; Chaurey \& Kandpal 2010; Claudy et al. 2011). Many researchers have identified that solar energy offers an important alternative to fossil fuels in generating electricity (Abdul Rahman \& Ismail 2008; Ab Kadir et al. 2010; Chua et al. 2011; Muhammad-Sukki et al. 2011) and that the technology of photovoltaics could be implemented in a typical rural house for any developing countries. This technology is a tool that can help Malaysian rural people to live independently without worrying on frequent power outages.

\section{The Case Study: Malaysian Rural Housing}

Malaysia's vernacular dwellings in rural areas are mainly built with gabled roofs, in order to adapt to the climatic elements (Fee et al. 2005). One study has indicated that PVs mounted on the roofs of rural houses in Malaysia could generate about $25 \%$ of current electricity demand (Byrd 2010b) which shows a significant proportion of the electricity generation mix for Malaysia. This is due to the larger roof area provided by rural housing in meeting the electricity requirements of low-energy households if to be compared with urban housing.

The case study selected was a typical vernacular rural house in Malaysia with a $16 \mathrm{~m}$ x $15 \mathrm{~m}$ floor plan, which is built on stilts (for the living room and 2 bedrooms) and an attached building for kitchen and bathroom. There is a $16 \mathrm{~m} \times 15 \mathrm{~m}$ gable roof and a $8.6 \mathrm{~m} \mathrm{x}$ $3.4 \mathrm{~m}$ mansard roof for the car porch. For the purposes of this paper, PV arrays would not cover the whole of a roof. Space is required for maintenance of both the roofs and the panels. However, since rural house types have an average roof area of typically $298 \mathrm{~m}^{2}$ (Yuan 1991) and a significant area is rectilinear, the collection area is more determined by the orientation and inclination of the roofs than their geometry. Typically, roof pitches in Malaysia are angled at $30^{\circ}$ or less, especially for long roof houses' type, a very well-known house type in Malaysia (Yuan 1991). The aspects that could limit the potential of the roofs to collect solar energy are the complexity of the roof form which can limit the number of solar panels and the overshadowing problems by trees or by any neighbouring houses.

Fig.2(a) and (b) presents the selected prototype of the rural house. The household's occupation duration was considered over 24 hours and divided into 3 types of occupants. The duration of occupancy can vary, which based on the lifestyles of the households, number of family members and type of occupations of the homeowners. Table 1 presents a brief description of each category. 


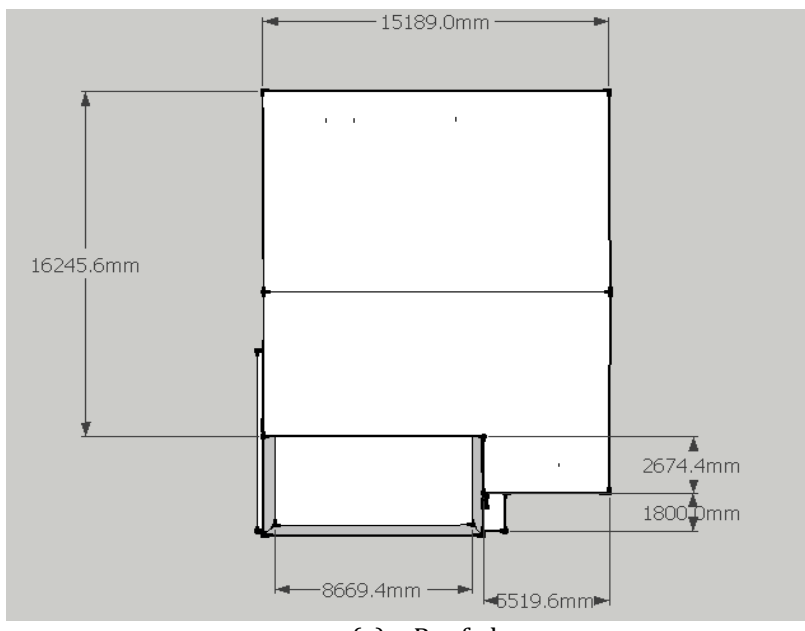

(a) Roof plan

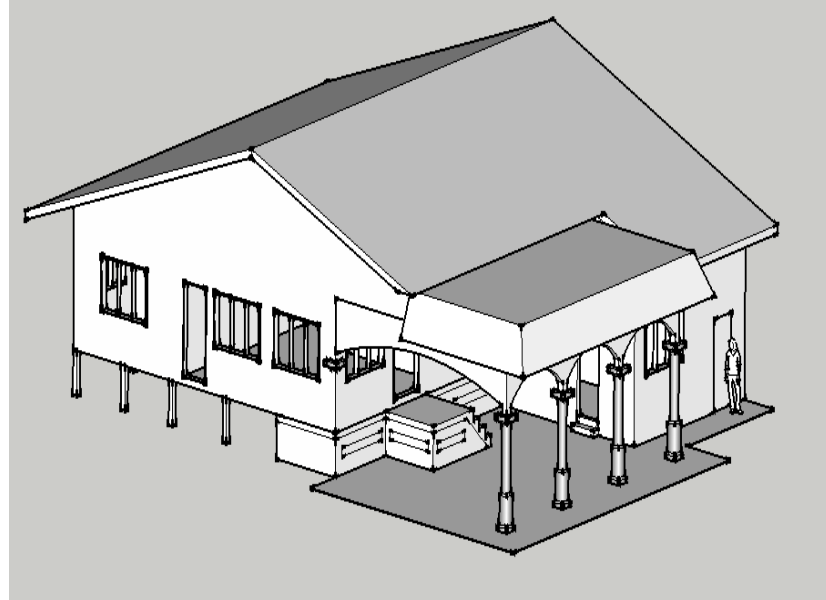

(b) 3D section

Fig. 2 Roof Planand 3-D SectionFor Rural House Prototype

Table 1

Types of occupants and electrical appliances consumption Types of Occupants

(i) Stay-at-home occupants

(ii) Fewer occupants at home

(iii)Working-outside occupants
Electrical appliances consumption

Electrical appliances are used from 6 am in the morning until midnight (all electrical appliances), whilst from midnight to early morning, appliances such as hand phone chargers, fans or night lamps might be used. Fridges run throughout the day.
Electrical appliances are used from 6 am in the morning, but between 8 am to 1 pm, the load profile decreased. There are less people in the house during this time (those that might be home include a housewife and kids) and those home will be using only a small numbers of appliances (e.g. washing machine and rice cooker). Fridges run throughout the day
Electrical appliances are used from 6 am to 8 am in the morning. Basically, significant electrical appliances such as the iron, electric kettle and rice cooker will be used in order to prepare food for breakfast and clothing for work. From 8 am to $5 \mathrm{pm}$; there will be no electric appliances used, since no family members are at home (except for fridge). Later in the day, appliances such as hand phone chargers, fans or night lamps might be used. Fridges run throughout the day.

\section{The Analysis}

For the purpose of this study, two stages of analysis will be conducted in order to determine the feasibility of solar PV energy in Malaysian rural housing. In the first stage, patterns of electricity consumption of rural dwellers will be identified. Three categories of load profiles were selected for this research and this has shown in Table 1.In order to signify a typical reading of the daily load profiles in Malaysian rural houses, every reading were assessed on the basis of daily electricity consumption (from 6 am to 6 am of the next day).

Next, all data from these daily load profiles is compiled and the potential of electricity energy from roofs based on solar PV technology is projected. This will help in identifying a feasible approach to offer a resilience solution for rural dwellers towards integrating solar PVs and electricity households. Domestic electrical load profiles for rural households in Malaysia are usually categorized as low energy, which is between $1 \mathrm{~kW}$ - $5 \mathrm{~kW}$ (TNB 2009). Reading differences may emerge due to the use of different electrical equipment in each household, but the load may not be as different as the types of electrical appliances used in the rural houses which will usually be the same (lamps, televisions, fans and refrigerators).

The load requirements would be high for certain times of the day, especially noon and night due to the fact that Malaysia is located in a tropical region. Usually, the people tend to use electric fans during this time of the day. However, during monsoon seasons in Malaysia (November to January), the weather would be slightly cooler and it is believed that during these months less electrical cooling appliances would be used, especially electricfans and air-conditioning system (Lau et al. 2010). Table 2 and Fig. 3 show the usage of electrical appliances for the three types of occupancy in rural Malaysia, excluding monsoon season.

\section{Solar Photovoltaic Potential}

Malaysia has a large solar-radiation resource, with an average irradiance per year of $1643 \mathrm{kWh} / \mathrm{m}^{2}$ (Chua et al. 2011). The potential generation of solar PV energy on Malaysian roofs is about 50\% more than that of roofs in Germany and Japan, where PVs have been widely implemented across the residential sector (Byrd 2010b). 
Tabel 2

The consumption of electricity for rural dwellings throughout the week

\begin{tabular}{|c|c|c|c|c|c|c|c|c|c|c|c|}
\hline \multicolumn{3}{|c|}{ TYPES OF OCCUPANTS : } & \multicolumn{3}{|c|}{ STAY-AT-HOME } & \multicolumn{3}{|c|}{ FEWER OCCUPANTS AT HOME } & \multicolumn{3}{|c|}{ WORKING OUTSIDE OCCUPANTS } \\
\hline Appliances & $\begin{array}{l}\text { Standard } \\
\text { Load } \\
\text { (Watts) } \\
\text { *from TNB }\end{array}$ & Quantity & $\begin{array}{c}\text { Daily } \\
\text { average } \\
\text { usage (h) }\end{array}$ & $\begin{array}{c}\text { Total } \\
\text { Wh/daily }\end{array}$ & kWh/daily & $\begin{array}{c}\text { Daily } \\
\text { average } \\
\text { usage (h) }\end{array}$ & Wh/daily & kWh/daily & $\begin{array}{c}\text { Daily } \\
\text { average } \\
\text { usage (h) }\end{array}$ & Wh/daily & kWh/daily \\
\hline $\begin{array}{l}\text { Fridge/ } \\
\text { Freezer }\end{array}$ & $500^{*}$ & 1 & 24 & 2400 & 2.400 & 24 & 2400 & 2.400 & 24 & 2400 & 2.400 \\
\hline Rice cooker & 905 & 1 & 1 & 905 & 0.905 & 1 & 905 & 0.905 & 0.4 & 362 & 0.362 \\
\hline Television & 100 & 1 & 10 & 1000 & 1.000 & 12 & 1200 & 1.200 & 5 & 500 & 0.500 \\
\hline $\begin{array}{c}\text { Table/stand } \\
\text { Fan }\end{array}$ & 60 & 2 & 16 & 1920 & 1.920 & 16 & 1920 & 1.920 & 7 & 840 & 0.840 \\
\hline Ceiling Fan & 120 & 1 & 11 & 1320 & 1.320 & 11 & 1320 & 1.320 & 5 & 600 & 0.600 \\
\hline $\begin{array}{l}\text { Washing } \\
\text { machine }\end{array}$ & 1080 & 1 & 0.15 & 162 & 0.162 & 0.3 & 324 & 0.324 & 0.3 & 324 & 0.324 \\
\hline $\begin{array}{c}\text { Fluorescent } \\
\text { Lights }\end{array}$ & 30 & 5 & 6 & 900 & 0.900 & 6 & 900 & 0.900 & 5 & 750 & 0.750 \\
\hline Bulb light & 70 & 2 & 6 & 840 & 0.840 & 6 & 840 & 0.840 & 5 & 700 & 0.700 \\
\hline Electric kettle & 1400 & 1 & 0.2 & 280 & 0.280 & 0.2 & 280 & 0.280 & 0.2 & 280 & 0.280 \\
\hline Iron & 1000 & 1 & 0.45 & 450 & 0.450 & 0.15 & 150 & 0.150 & 0.15 & 150 & 0.150 \\
\hline \multicolumn{5}{|c|}{ TOTAL LOAD FOR COMMON ELECTRICITY APPLIANCES: } & 10.177 & & & 10.239 & & & 6.906 \\
\hline \multicolumn{12}{|c|}{ Others: } \\
\hline $\begin{array}{c}\text { Cell phone } \\
\text { chargers }\end{array}$ & 35 & 2 & 8 & 560 & 0.560 & 9 & 630 & 0.630 & 9 & 630 & 0.630 \\
\hline Blender & 300 & 1 & 0.3 & 90 & 0.090 & 0.3 & 90 & 0.090 & 0.15 & 45 & 0.045 \\
\hline $\begin{array}{c}\text { Microwave/ } \\
\text { Oven }\end{array}$ & 1100 & 1 & 0.1 & 110 & 0.110 & 0.05 & 55 & 0.055 & 0.05 & 55 & 0.055 \\
\hline Radio & 20 & 1 & 7 & 140 & 0.140 & 5 & 100 & 0.100 & 0 & 0 & 0.000 \\
\hline $\begin{array}{c}\text { ASTRO-set } \\
\text { (Satellite TV) }\end{array}$ & 200 & 1 & 10 & 2000 & 2.000 & 12 & 2400 & 2.400 & 5 & 1000 & 1.000 \\
\hline Computer & 200 & 1 & 8 & 1600 & 1.600 & 4 & 800 & 0.800 & 3 & 600 & 0.600 \\
\hline Night Lamp & 70 & 1 & 9 & 630 & 0.630 & 9 & 630 & 0.630 & 9 & 630 & 0.630 \\
\hline \multicolumn{5}{|c|}{ TOTAL LOAD (kWh) FOR OPTIONAL APPLIANCES: } & 5.130 & & & 4.705 & & & 2.960 \\
\hline \multicolumn{5}{|c|}{ OVERALL TOTAL (kWh/daily) } & 15.307 & & & 14.944 & & & 9.866 \\
\hline
\end{tabular}

* Data is based on typical electrical appliances which are used in rural Malaysia (Excludes school holidays and weekends).

Note: Stay-at-home (Occupants always at home on daily-basis), Fewer occupants at home (Few people at homes during the day, such as housewife and kids), Working outside occupants (Nobody at home during the day).

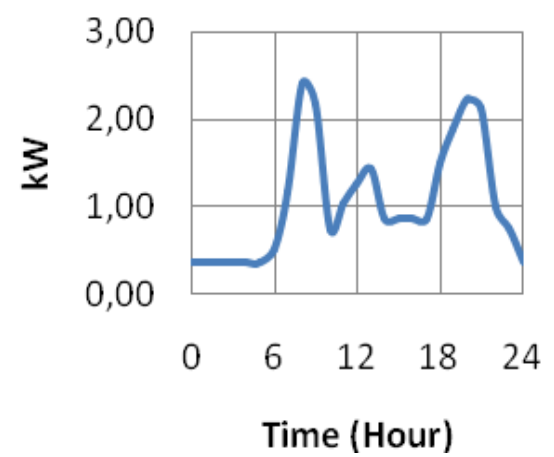

(a) 'Stay-at-home'

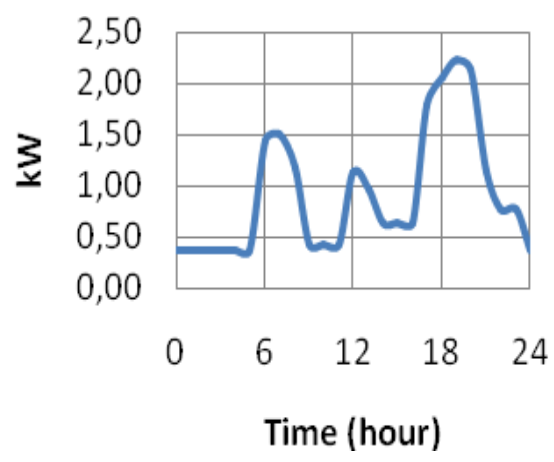

(b) Fewer occupants' at home

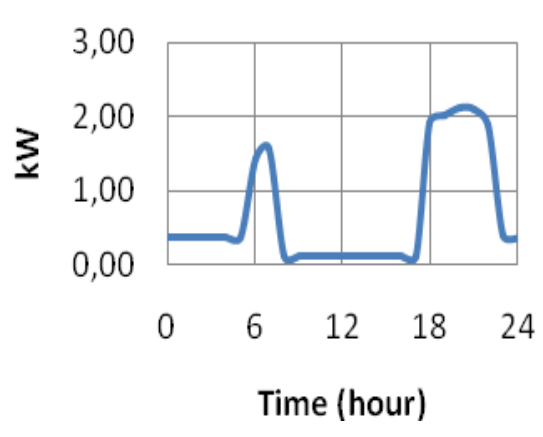

(c) 'Working outside'

Fig. 3 The load profile for a typical rural occupancy 
Residential buildings in rural areas correspond to over $27 \%$ of the electricity demand in Malaysia (TNB 2009).

\subsection{Solar PV Characteristics}

Based on a study, the solar radiation in Malaysia reaches its peak emission at noon, with the reading reaching up to $1000 \mathrm{~W} / \mathrm{m}^{2}$ on a clear day (see Fig. 4) (Ibrahim 2009). Today, PV panels convert energy from sunlight into electric energy within the range of $7 \%$ 17\% (Gratzel 2005). It has been assumed that these PVs work in tropical temperatures, with pre-photovoltaic losses (dirt and shadows) of $8 \%$, system losses (cable and inverter losses of $5 \%$ and maintenance downtime of $6 \%$ ), tilt and orientation losses of $5 \%$, module losses of $50 \%$ and thermal losses of $10 \%$ (Erge and Haw 2003). This gives an overall solar energy to electricity conversion efficiency of $16 \%$.

For the purposes of this study, a $2 \mathrm{kWp}$ and $4 \mathrm{kWp}$ capacity output of a $16 \%$-efficient PV system are selected.

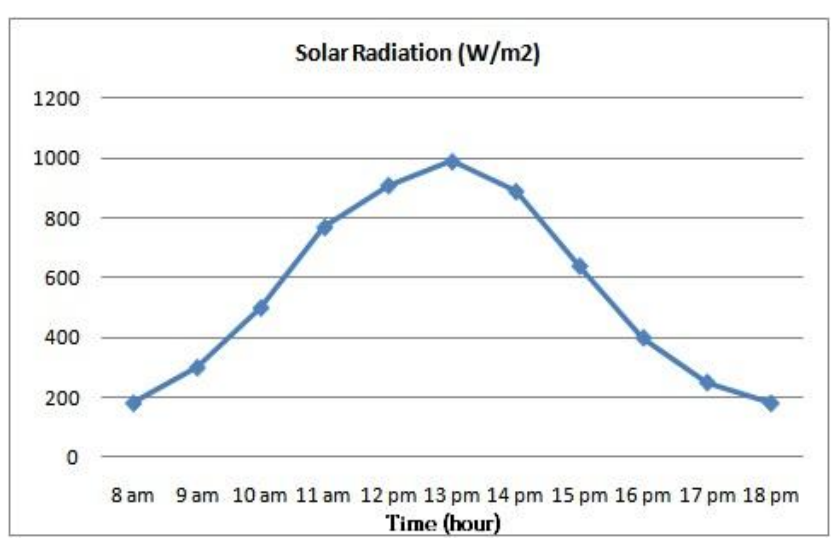

Fig. 4 Annual solar radiation data $\left(\mathrm{W} / \mathrm{m}^{2}\right)$ daily (Source: Adapted from Ibrahim, et.al., 2009)
Based on the rule of thumb derived from NREL guideline, 14.8 and 29.7 square meters of roof area are needed for a $2 \mathrm{kWp}$ and $4 \mathrm{kWp}$ PV system, respectively (NREL 2003) (See Table 3). This requires only $10 \%$ of the roof area of a typical rural house in Malaysia.

\subsection{Pattern of electricity output from a $2 \mathrm{kWp}$ and $4 \mathrm{kWp}$ PV system.}

Figure 5 demonstrates the patterns of electricity output for a $2 \mathrm{kWp}$ and $4 \mathrm{kWp}$ PV system in comparison with the households' energy demand (for the 3 types of occupancy) for rural dwellings. The red curve represents a $4 \mathrm{~kW}$ PV system, the green curve represents a $2 \mathrm{~kW}$ PV system and the blue curve represents the load profile of the house. During the day (from 7 am - $6 \mathrm{pm}$ ), the amount of solar energy available is 2 times greater than the house's total demand, indicating a significant link between the availability of solar energy and the electricity loads of the house. From Fig. 5, it can be seen that PVs supply $35 \%$ more electricity than is consumed over a 24 hour period. Based on these 3 graphs, there is actually a welldefined 'potential spot' for solar energy, depending on the occupant's patterns of electricity use (Walker 1995).

During the day, a house would only consume 1/3rd of the electricity it produces. These results show the considerable potential of solar energy for the building where $2 / 3$ rd of the energy could be fed into the power grid or stored in batteries (e.g for electric vehicle) in the future.

It should be highlighted that these results are based on there being no shading effects from the surroundings. Although this analysis was carried out over a 24 hour period, Malaysia is a tropical country with little seasonal variation and so this analysis can be extrapolated to apply to annual electricity supply and demand.

Tabel 3

Solar output based on $2 \mathrm{~kW}$ and $4 \mathrm{~kW}$ PV power system

\begin{tabular}{|c|c|c|c|c|c|c|c|c|}
\hline \multicolumn{3}{|c|}{ Characteristics } & \multicolumn{3}{|c|}{$2 \mathrm{~kW}$ power system } & \multicolumn{3}{|c|}{$4 \mathrm{~kW}$ power system } \\
\hline Time & $\mathrm{W} / \mathrm{m}^{2}$ & $\begin{array}{c}\text { PV system } \\
\text { efficiency (\%) }\end{array}$ & $\begin{array}{l}\text { Area of roof }\left(\mathrm{m}^{2}\right) \\
(\mathrm{NREL}, 2003)^{*}\end{array}$ & $\begin{array}{l}\text { Solar output } \\
\text { (Watts) }\end{array}$ & $\begin{array}{c}\text { Solar output } \\
(\mathrm{kW})\end{array}$ & $\begin{array}{l}\text { Area of roof }\left(\mathrm{m}^{2}\right) \\
(\mathrm{NREL}, 2003)^{*}\end{array}$ & $\begin{array}{l}\text { Solar output } \\
\text { (Watts) }\end{array}$ & $\begin{array}{c}\text { Solar } \\
\text { output } \\
(\mathrm{kW})\end{array}$ \\
\hline 8 & 180 & 0.16 & 14.8 & 426.24 & 0.4 & 29.7 & 855.36 & 0.9 \\
\hline 9 & 300 & 0.16 & 14.8 & 710.4 & 0.7 & 29.7 & 1425.6 & 1.4 \\
\hline 10 & 500 & 0.16 & 14.8 & 1184 & 1.2 & 29.7 & 2376 & 2.4 \\
\hline 11 & 780 & 0.16 & 14.8 & 1847.04 & 1.8 & 29.7 & 3706.56 & 3.7 \\
\hline 12 & 940 & 0.16 & 14.8 & 2225.92 & 2.2 & 29.7 & 4466.88 & 4.5 \\
\hline 13 & 1000 & 0.16 & 14.8 & 2368 & 2.4 & 29.7 & 4752 & 4.8 \\
\hline 14 & 920 & 0.16 & 14.8 & 2178.56 & 2.2 & 29.7 & 4371.84 & 4.4 \\
\hline 15 & 640 & 0.16 & 14.8 & 1515.52 & 1.5 & 29.7 & 3041.28 & 3.0 \\
\hline 16 & 400 & 0.16 & 14.8 & 947.2 & 0.9 & 29.7 & 1900.8 & 1.9 \\
\hline 17 & 240 & 0.16 & 14.8 & 568.32 & 0.6 & 29.7 & 1140.48 & 1.1 \\
\hline 18 & 180 & 0.16 & 14.8 & 426.24 & 0.4 & 29.7 & 855.36 & 0.9 \\
\hline
\end{tabular}




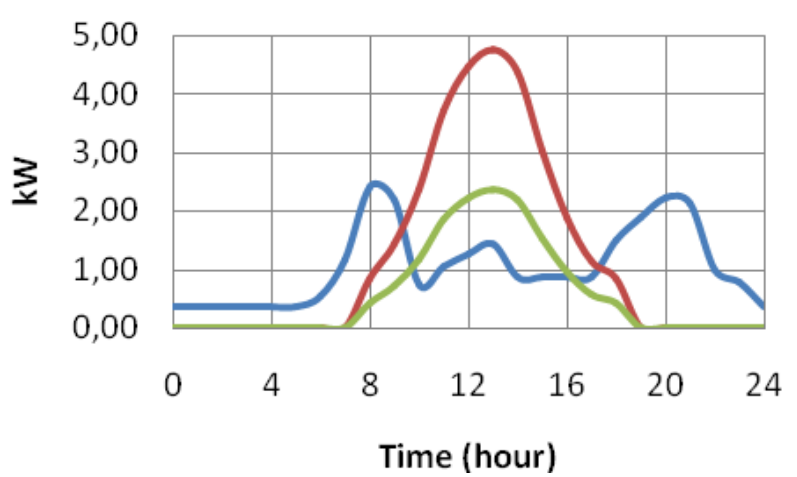

(a) Stay-at-home occupants

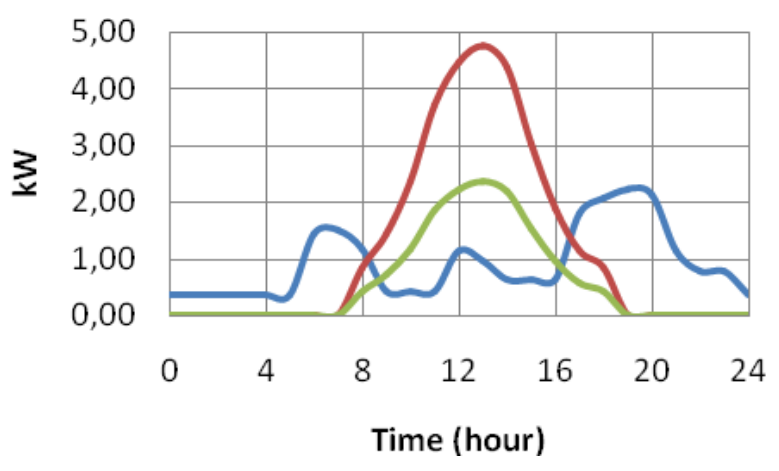

(b) Fewer occupants at home

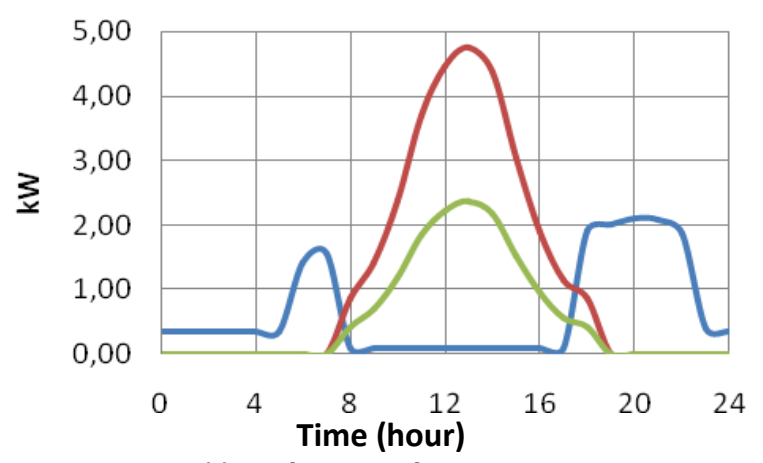

(c) working outside occupants

Fig. 5 The pattern of solar PV electricity generation for a typical rural house

\section{The Cost-Benefit Analysis}

For this section, a cost-benefit analysis will be made in order to identify (i) the savings that can be gained by the homeowners and (ii) to determine the payback period for installing a PV system onto a house. This is essential, in order to attract people to install a PV system.

\subsection{Calculations for Savings in Electricity bill per month}

Based from Table 2, the overall total load (kWh) for a rural house is estimated to be $450 \mathrm{kWh}$ per month. Table 4 shows the actual expenses for monthly electricity bill for a rural house.

Based on Fig. 5, it can be estimated that by installing $4 \mathrm{kWp}$ PV system for a house; it will produce $2.5 \mathrm{kWh}$ of electricity per day/75 kWh per month. With a simple calculation (450 kWh - $75 \mathrm{kWh}=375 \mathrm{kWh})$, the monthly electricity bill can be decreased to RM107.00 per month/ RM1284.00 per annum, thus saving around RM 31.00 per month/RM 372.00 per annum.With an estimated increase of electricity prices up to $5 \%$ per year in the future (Fantazzini et al. 2011; Schuman 2012), the price of electricity will increase up to RM 0.82 per unit $(\mathrm{kWh})$ by the year 2030. Fig. 6 shows the projection of escalating price for electricity in Malaysia-
Tabel 4

Actual expenses for monthly electricity bill for a rural house (450 kWh power consumption)

\begin{tabular}{ccccc}
\hline $\begin{array}{c}\text { Electricity } \\
\text { unit in } \\
\text { Malaysia }\end{array}$ & $\begin{array}{c}\text { Malaysia's } \\
\text { Electricity } \\
\text { tariff* }\end{array}$ & $\begin{array}{c}\text { Maxi } \\
\text { mum } \\
\text { kWh }\end{array}$ & $\begin{array}{c}\text { Your } \\
\text { Consump- } \\
\text { tion (kWh) }\end{array}$ & $\begin{array}{c}\text { Amount } \\
\text { (RM) }\end{array}$ \\
\hline $\begin{array}{c}\text { First 200 units } \\
(0-200)\end{array}$ & $\mathbf{0 . 2 1 8}$ & 200 & 200 & $\mathbf{4 3 . 6 0}$ \\
$\begin{array}{c}\text { Next } 100 \text { units } \\
(201-300)\end{array}$ & $\mathbf{0 . 3 3 4}$ & 100 & 100 & $\mathbf{3 3 . 4 0}$ \\
$\begin{array}{c}\text { Next 100 units } \\
(301-400)\end{array}$ & $\mathbf{0 . 4 0 0}$ & 100 & 100 & $\mathbf{4 0 . 0 0}$ \\
$\begin{array}{c}\text { Next 100 units } \\
(401-500)\end{array}$ & $\mathbf{0 . 4 2 0}$ & 50 & 50 & $\mathbf{2 1 . 0 0}$ \\
\hline & *TNB tariff & & Total & $\mathbf{1 3 8 . 0 0}$ \\
\hline
\end{tabular}

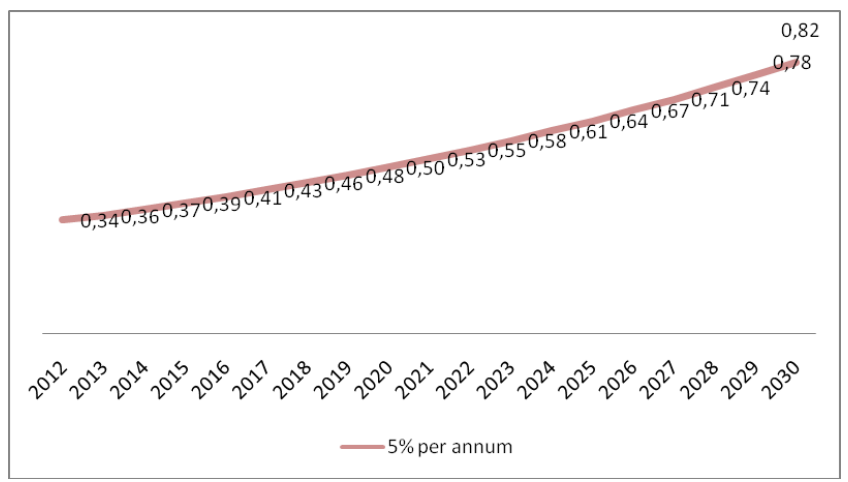

Fig. 6 The projection of electricity prices escalation(2012-2030) 
Citation: Ahmad, N.A. \& Byrd, H. (2013) Empowering Distributed Solar PV Energy for Malaysian Rural Housing: Towards Energy Security and Equitability of Rural Communities. Int. Journal of Renewable Energy Development, 2(1), 59-68

P a g e $\mid \mathbf{6 6}$

from 2012 to 2030. Thus, by providing an opportunity to install solar PV panel for rural people, it will help them to reduce their electricity bills, provide an income from selling excess electricity back to the grid through the Feed-in-Tariff (FiT) scheme and, at the same time, has the potential to help 3.5 million rural houses in Malaysia (Department of Statistic Malaysia 2010) not to be burdened with escalating electricity costs.

\subsection{Calculation of Simple Payback Period}

Based on data from the Sustainable Energy Development Authority Malaysia (SEDA), the feed-intariff (FiT) rate for solar energy in Malaysia (up to $4 \mathrm{~kW}$ capacity) is RM1.13 per kWh (with a contract period of 21 years) and will continuously to reduce to RM1.04 in the year 2014 (SEDA 2012). The cost of installing a PV panel is decreasing, from RM 31,000 per kWP in early 2005 (SEDA 2012) to RM 19, 120.00 per kWp in 2010 (Muhammad-Suki et al. 2011). Full installation cost will be based on this figure, but for a larger installation (2 $\mathrm{kWp}$ and $4 \mathrm{kWp}$ ), there will be a $10 \%$ cost reduction per $1 \mathrm{kWp}$ installed due to economic scale, which translates to RM 36, 270.00 and RM 48, 000.00 (Bosh Energy 2010 ) respectively.

In assuming all electricity is fed into the grid, a simple payback period plan can be determined and can be used to attract homeowners to install solar PV system. This result depends on the location of installation and with the assumption of no interest on the installation cost.

For a calculation of a simple payback period as shown in Table 5, we have assumed 2 options, which consist of, (a) no interest during the process of installing PV systems; either because the PVs were bought without a loan or because of a $100 \%$ loan subsidy and (b) PVs were bought using a private loan from local banks with $6 \%$ interest rate per annum (Bank Negara Malaysia 2011).

From Table 5, it is found that the best option is to choose $4 \mathrm{kWp}$ PV system, where the duration for the homeowner to gain returns on the PV investment is shorter compared to $2 \mathrm{kWp}$ PV system. Nonetheless, the payback period of $4 \mathrm{kWp}$ PV system is different between option (a) and option (b) which are 8.4 and 16 years respectively. From this result, it has highlights the importance of a subsidy for low income households in order to install a solar PV system. The roofs of rural houses have the potential to generate surplus electricity in order to satisfy occupants needs if a PV array can be installed on at least $10 \%$ of the roof area (between 14 $\mathrm{m} 2$ to $29 \mathrm{~m}^{2}$ ), based on solar output performance.

Further studies will be needed in order to establish a specific program or loans that could make PVs financially attractive to the locals. Involvements by the Government, stakeholders and the people are important in order to understand the energy needs of the people, the potential and opportunities to explore and expand -
Tabel 5

Calculation for a simple payback period for rural housing (using 2 kwp and 4 kwp pv system)

\begin{tabular}{|c|c|c|c|}
\hline & ITEM & $\begin{array}{c}2 \mathrm{kWp} \\
(\mathrm{RM})\end{array}$ & $\begin{array}{c}4 \mathrm{kWp} \\
(\mathrm{RM})\end{array}$ \\
\hline 1 & Installation Cost (RM) (1) & 36270.00 & 48000.00 \\
\hline \multirow[t]{3}{*}{2} & $\begin{array}{l}\text { Total revenue (annually) } \\
{ }^{*} \text { FiT [RM } 1.13 \times \text { Generation of } \\
\text { electricity] for a year } \\
\text { (a) } 2 \mathrm{kWp}=\end{array}$ & & \\
\hline & $\begin{array}{l}\text { RM } 1.13 \times 3000 \mathrm{kWh} / \text { year }^{(1)} \\
\text { (b) } 4 \mathrm{kWp}=\end{array}$ & 3390.00 & \ulcorner \\
\hline & RM1.13 x 5080 kWh/year(1) & - & 5470.00 \\
\hline
\end{tabular}

3 Payback period (Year)

Option (a) Without interest

* Installation Cost:

10.7 years $\quad 8.4$ years

Total revenue (annually)

Option (b) With 6\% interest(2)

* Installation Cost:

26 years 16 years

[Total revenue (annually) - (Installation Cost x 6\% per annum)]

(1) Data from Malaysia Bosch Solar Energy

(2) Interest rate is based from private loans provided by Maybank, Bank Rakyat and Bank Simpanan Nasional

this technology into a widespread basis. Concrete strategies are needed in order to evaluate many pushfactors for the diffusion of solar PV energy, especially in determining suitable policies, energy action plan, financing scheme, incentives and many more.

\section{Conclusion}

Rural people in Malaysia need to be fully exposed on the beneficial side of solar PV energy before any consideration on starting the energy project in order to avoid any unsuccessful projects in the near future. An extensive analysis should be introduced on surplus electricity and whether selling excess electricity to the power grid or running electric vehicles (EV) is more costeffective in the future. In order for the system to allow a surplus of electricity that can be fed into the grid to run electric vehicles, the areas of PV panel would need to be extended. This could be implemented when the price of electric cars or motorbikes becomes competitive in a few years time. To what degree this can be done depends on the total of electricity that can be generated by the house. Instead of just copying and adopting any solar PV energy projects from overseas, local knowledge, characteristics and skills need to be explored in order to develop RE projects for rural Malaysia.

In addition, with current feed-in tariffs provided by Tenaga Nasional Berhad, households can profit from their renewable electricity within an acceptable payback period of 8-16 years. This means that rural households can move towards being more self-sufficient in terms of electricity and can also mitigate the unforeseen future of Malaysia by participating into feed-in tariff scheme that involves national solar electricity. The degree to which 
rural houses can participate in diffusing this technology has not yet been considered. It will depend on the acceptance and knowledge of the community, the number of houses that invest in this technology and also the capacity of the national grid to utilize this electricity. It is hoped in the near future, the technology is able to convince people in Malaysian rural areas to produce their own electricity.

\section{Acknowledgment}

The authors would like to express their sincere gratitude to the Ministry of Higher Education (MOHE) Malaysia, The University of Auckland and Faculty of Architecture, Planning and Surveying, UiTM Perak for funding this research.

\section{References}

Ab Kadir, M.Z.A., Y. Rafeeu, \& Adam, N.M. (2010) Prospective Scenarios for The Full Solar Energy Development in Malaysia. Renewable and Sustainable Energy Reviews, 14(9), 3023-3031.

Abdul Rahman, A.M. \& Ismail M.R. (2008) Future Design In An Energy Efficient Building As An Identity of A Malaysian Tropical Architecture With Emphasis On Photovoltaic Technology And Passive Solar Building Design Elements. Available from: http://eprints.usm.my/4894/.

Ali, R., Daut, I. \& Taib, S. (2012) A review on existing and future energy sources for electrical power generation in Malaysia. Renewable and Sustainable Energy Reviews, 16(6): p. 4047-4055.

APEC (2006) Energy Demand and Supply Outlook 2006, Asia Pacific Energy Research Centre p. 49-53.

Arun, P.S. (1991) Power Shortages in Developing Countries: Impacts and Policy Implications. Energy Policy, 19(5), 425-440.

Bank Negara Malaysia (2011) List of Licensed Banking Institutions in Malaysia 2011 [cited 2012; Available from: http://www.bnm.gov.my/index.php?ch=13\&cat=banking.

Bosch Energy (2010) Bosch Solar Energy AG Solar Panel Price.

Byrd, H. (2010)a Energy and Ecology: A View of Malaysia Beyond 2020. Penang: USM Publisher.

Byrd, H. (2010)b, The Potential of PVs In Developing Countries Maintaining An Equitable Society In The Face Of Fossil Fuel Depletion, in International Conference on Environment 2010, USM USM: Penang.

California Energy Commission (2012). Rotational or Rolling Blackouts. [cited 2013 30/01/2013]; Available from: http://www.consumerenergycenter.org/tips/blackouts.html.

Campren, B.V., Guidi, D. \& Best, G. (2000), Solar Photovoltaics For Sustainable Agriculture and Rural Development, in Envvironment and Natural Resources. p. 76. E.a.N.R.S.S.D. Department, Food and Agriculture Organization of the United Nations: Rome.

Chaurey, A. \& Kandpal, T.C. (2010) Assessment and Evaluation of PV based Decentralized Rural Electrification: An overview. Renewable and Sustainable Energy Reviews, 14(8), 2266-2278.

Chua, S.C., T.H. Oh, \& Goh, W.W. (2011) Feed-in tariff outlook in Malaysia. Renewable and Sustainable Energy Reviews, 15(1): 705712.

Claudy, M.C., C. Michelsen, \& O'Driscoll, A. (2011) The Diffusion of Microgeneration Technologies - Assessing The Influence of Perceived Product Characteristics on Home Owners' Willingness to Pay. Energy Policy, 39(3), 1459-1469.

Department of Statistic Malaysia (2010) Preliminary Count Report, p. 47. Department of Statistic Malaysia, Government of Malaysia Putrajaya.

Department of Statistic Malaysia (2011) Taburan Penduduk dan CiriCiri Asas Demografi in Census 2010, p. 5. Kuala Lumpur.
Economic Planning Unit (2005) Development Plan of Malaysia: Midterm $8^{\text {th }}$, Kuala Lumpur.

EIA (2008) International Energy Annual 2008 Energy Information Administration (EIA). Official Energy Statistics from the U.S Government [cited 2011 21.05]; Available from: $<$ http://www.eia.doe.gov/>.

Erge, T. \& Haw L.C. (2003) PV in buildings for Malaysia: prototype solar house. in Photovoltaic Energy Conversion, Proceedings of 3rd World Conference.

Fantazzini, D., Höök, M. \& Angelantoni, A. (2011) Global Oil Risks in The Early $21^{\text {st }}$ Century. Energy Policy, 39(12), 7865-7873.

Fee, C.V., Sani, A., Nidzam, A., Barlow, H. S., Michael, J., Gurupiah (2005) The Encyclopedia of Malaysia, Volume 5 : Architecture, ed. C.V. Fee. Vol. 5., p. 60. Kuala Lumpur: Archipelogo Press.

Grätzel, M. (2005) Solar Energy Conversion by Dye-Sensitized Photovoltaic Cells. Inorganic Chemistry, 44(20), 6841-6851.

Hamid, K.A. \& Rashid, Z.A. (2012) Chapter 9: Economic Impacts of Subsidy Rationalization Malaysia, in Energy Market Integration in East Asia: Theories, Electricity Sector and Subsidies, Y. Wu, X. Shi, and F. Kimura., p. 207-252. ERIA: Jakarta.

Hann, W.C. (2012) Oil and Gas, M.K. Eng, Maybank Investment Bank Berhad: Malaysia.

Harrabin, R. (2009), $U K$ 'could face blackouts by 2016', in $B B C, \mathrm{BBC}$ : UK.

Ibrahim, M., Sopian, K., Daud, W. R. W., \& Alghoul, M. A. (2009) An Experimental Analysis of Solar-Assisted Chemical Heat Pump Dryer. International Journal of Low-Carbon Technologies, 4(2), 7883.

International Gas Union (IGU) (2011), World LNG Report 2011, The Malaysian Gas Association and PETRONAS Malaysia, p. 65. Office of the Secretary General: Kuala Lumpur.

Lau, K.Y., Yousof, M.F.M., Arshad, S. N. M., Anwari, M. \& Yatim, A. H. M. (2010) Performance Analysis of Hybrid Photovoltaic/Diesel Energy System under Malaysian Conditions. Energy, 35(8), 32453255 .

Luke, T.W. (2010) Power Loss or Blackout: The Electricity Power Collapse of August 2003 in North America, in Disrupted Cities: When Infrastructure Fails, p. 196. S. Graham, Routledge: UK.

Malaysia (2010) 10th Malaysia Plan (2011-2015), Department of Prime Minister, Editor, The Economic Planning Unit.

MBIPV (2011) PV System Cost. Available from: http://www.mbipv.net.my/content.asp?zoneid=4\&categoryid=12

Mohamed, A.R. \& K.T. Lee (2006) Energy for Sustainable Development in Malaysia: Energy Policy and Alternative Energy. Energy Policy, 34(15), 2388-2397.

Muhammad-Sukki, F., Ramirez-Iniguez, R., Abu-Bakar, S. H., McMeekin, S. G., \& Stewart, B. G. (2011) An Evaluation of The Installation of Solar Photovoltaic in Residential Houses in Malaysia: Past, Present, and Future. Energy Policy, 39(12), 79757987

Muri, M. (2003) OPEC and Asia: The changing structure of the oil market-Malaysia, Energy, 11(4-5): p. 481-482.

Naidu, G. (2010) Chapter 7: Infrastructure Development in Malaysia, in International Infrastructure Development in East Asia - Towards Balanced Regional Development and Integration, N. Kumar, p. 204227. Editor. Economic Research Institute for ASEAN and East Asia.

Noh, C.K.M. (2012) Overview on the Energy Resources in Malaysia, Tenaga Nasional Berhad (TNB), Editor.

NREL (2003) A Consumer's Guide: Get Your Power From the Sun, US Department of Energy, p. 20. The US Government,: Washington.

Saidur, R., Masjuki, H. H., Jamaluddin, M. Y., \& Ahmed, S. (2007) Energy and Associated Greenhouse Gas Emissions from Household Appliances in Malaysia. Energy Policy, 35(3), 1648-1657.

Schuman, M. (2012) How High Will Global Oil Prices Rise?, in Time: Business, Time Inc: US.

SEDA (2012) FiT Rates for solar PV. Available from: http://seda.gov.my/.

Suruhanjaya Tenaga (2007) Electric Supply Industry in Malaysia Performance and Statistical Information 2007, Energy Commission.

The International Energy Agency (IEA) (2012) Medium-Term Coal Market Report (MCMR)-Market Trends and Projections to 2017, 
Citation: Ahmad, N.A. \& Byrd, H. (2013) Empowering Distributed Solar PV Energy for Malaysian Rural Housing: Towards Energy Security and Equitability of Rural Communities. Int. Journal of Renewable Energy Development, 2(1), 59-68

$\mathrm{P}$ a g e $\mid \mathbf{6 8}$

in Medium-Term Market Report Series, p. 148. The International Energy Agency (IEA): USA.

TNB (2009) Powering The Nation (1949 - 2009), p. 313. Tenaga Nasional Berhad: Malaysia.

TNB (2010) Pricing and Tariff. 2 Sept 2011; Available from: http://www.tnb.com.my/residential/pricing-and-tariff.html.

Walker, G. (1995) Renewable Energy and The Public. Land Use Policy, 12(1), 49-59.
Watson, J., Sauter, R., Bahaj, B., James, P., Myers, L., \& Wing, R. (2008) Domestic micro-generation: Economic, regulatory and policy issues for the UK. Energy Policy, 36(8), 3095-3106.

Yuan, L.J. (1991) Part II: Indigenious and traditional knowledge and practices, in The Malay House: Rediscovering Malaysia's Indigenous shelter system. p. 152. Institut Masyarakat: Kuala Lumpur. 